\title{
Measurements of Fog Water Deposition on the California Central Coast
}

\author{
Cyrus Hiatt $^{1,2}$, Daniel Fernandez ${ }^{1}$, Christopher Potter ${ }^{2}$ \\ ${ }^{1}$ California State University Monterey Bay, Seaside, USA \\ ${ }^{2}$ NASA Ames Research Center, Mountain View, USA \\ Email: chris.potter@nasa.gov
}

Received May 3, 2012; revised June 6, 2012; accepted June 16, 2012

\begin{abstract}
Fog deposition is a notable component of the water budget of herbaceous-shrub ecosystems on the central and southern coastal regions of California. This paper presents an analysis of fog water deposition rates and meteorological controls in Big Sur, California. Mesh-screen fog collectors were installed the Brazil Ranch weather station sites to measure fog water during the summer seasons of 2010 and 2011. Fog deposition occurred during $73 \%$ of days recorded in 2010 and $87 \%$ of days recorded in 2011 . The daily average deposition rate was $2.29 \mathrm{~L} / \mathrm{m}^{2}$ in 2010 and $3.86 \mathrm{~L} / \mathrm{m}^{2}$ in 2011 . The meteorological variables which had the greatest influence on prediction of fog deposition were wind speed, wind direction, and the dew-point depression (difference between air temperature and dew point). Based on these results, we hypothesize that high rates of summer fog deposition help sustain the productivity of California coastal vegetation through periods of low rainfall.
\end{abstract}

Keywords: Fog; Deposition; California; Water Budget

\section{Introduction}

The presence of fog on the California Central Coast has been linked to numerous important bio-physical processes, including moderation of surface temperatures and increase of relative humidity [1-3]. With respect to vegetation interactions, coast redwood [Sequoia sempervirens (D. Don) Endl.] has been studied for effects of cloud moisture within the canopy, which may reduce the atmospheric water vapor pressure deficit and cause transpiration and movement of vascular fluid to slow markedly $[4,5]$. Under certain wind conditions, coastal shrub foliage may trap advected fog water and drip moisture into the surrounding soil below to mediate losses due to evapotranspiration $[4,6,7]$.

The physical processes leading to coastal fog formation on the Pacific coast have been studied for decades. Warm surface air blowing over cold upwelling ocean water near the California coast is cooled to create a surface-based inversion. Petterssen [8] reported that radiative cooling of the fog layer, together with heating from the sea surface, initiates mixing and lifting of the marine inversion. The well-mixed marine boundary layer is topped by such an inversion at a height of $100-600 \mathrm{~m}$ [9]. Subsidence acts to strengthen the inversion above the stratus cloud top and forces lowering of clouds [10], which can move ashore with sustained winds to generate fog over land.
Despite a strong understanding of fog formation processes along the Pacific coast, little is known about the amounts of water that can be deposited on ocean-facing ridges of the coastal California at different times of the year. This paper presents an analysis of fog water deposition rates and meteorological controls on shrub- and grass-covered slopes of Big Sur, California. Coastal shrub cover on ocean-facing ridges in this region have a high degree of biological diversity and endemism, and provide critical habitat for a large number of rare, endangered, and threatened animal and plant species [11]. The water budgets of mixed herbaceous-shrub communities are of interest because they dominate the central and southern coastal regions of California.

A number of other studies have examined the relationship between some of these meteorological controls and the prediction of fog. For example, one study in Monterey worked to predict west coast fog by applying large-scale synoptic weather events with inversion-based statistics [12]. Others have attempted to apply large-scale numerical models to the prediction of fog on a meso- to large-scale basis [13] or at a single site for the purpose of prediction of fog at an airport [14]. Other, more regional, studies have examined the direct relationship between relative humidity, temperature and wind patterns in relation to fog water collection [15]. While a significant number of studies have sought to predict or forecast the 
occurence of fog based on apriori conditions, relatively few have examined the relationships between fog and existing meteorological conditions with the intention to determine valid proxies for fog deposition water to the land surface. The objective of this study was to understand and quantify the meteorological controls, namely temperature, dew point, wind speed, direction, and relative humidity, on fog water deposition rates for the coastal grassland and shrublands of central California using measurements collected over two field seasons.

\section{Study Site}

The primary research site is located at the Brazil Ranch (center coordinates: latitude $36.35^{\circ} \mathrm{N}$, longitude $121.88^{\circ}$ W) near Big Sur, California (Figure 1). The Brazil Ranch is named after Tony and Margaret Brazil and the pioneer family that worked to establish the land as a farm, ranch, as well as a dairy operation in the early 20th century. Today, the property serves as a primary research site for the US Forest Service to monitor and manage vegetation, wildlife, water quality, and sensitive coastal habitats.

Drier, southeast-facing slopes share a relatively equal distribution of coyote bush (Baccharis pilularis) and California coffeeberry (Rhamnus californica) along with some California sagebrush (Artemisia californica) [16]. The coastal scrub community is usually a successional plant community that, in the absence of fire, gradually moves into herbaceous cover where the soil depth transitions from the shallowest to intermediate depth. The herbaceous plant community includes California annual grassland series and California oatgrass series. Coastal sage scrub and chaparral are known as secondary pioneer plant in California grasslands, which invade grassland and increase in the absence of fire or grazing. We noted a propagation of the introduced Cape ivy (Delairea odorata) during our field work. Cape ivy, a vine native to South Africa, has become a significant threat to coastal scrub.

\section{Data and Methods}

Two Campbell weather stations, each equipped with a

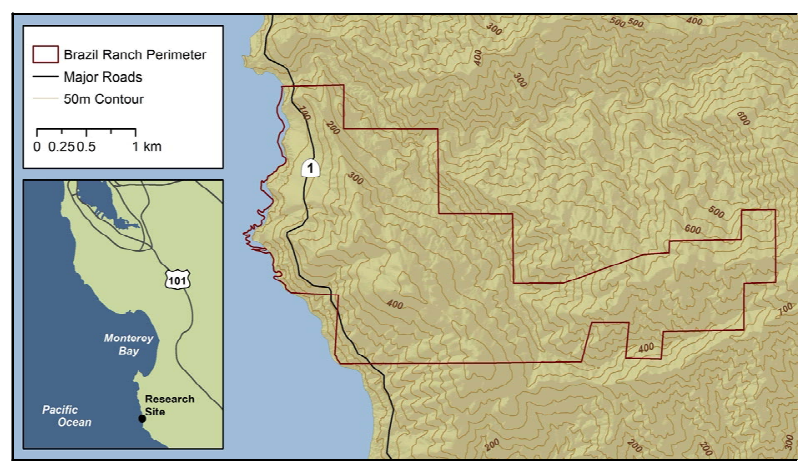

Figure 1. Study site.
CR800 data logger, a 03001 R.M. Young Wind Sentry Set, and an HMP45C Temperature and Relative Humidity Probe were installed at the Brazil Ranch in 2007 (Figure 2). The on-going hourly meteorological data collection included air temperature, humidity, wind speed and direction, solar irradiance, and precipitation (as rainfall).

Mesh-screen fog collectors were installed at the Brazil Ranch weather station sites in June 2010 (Figure 2). The fog collector design (also called a Standard Fog Collector, or SFC) is a polypropylene mesh (triangular weave of flat fiber, $1 \mathrm{~mm}$ wide and $0.1 \mathrm{~mm}$ thick) fastened to a metal $1 \times 1$ meter vertical frame [17] (Figure 3). A metal trough directly under the frame collected water that dripped from the mesh and funneled the water flow to a

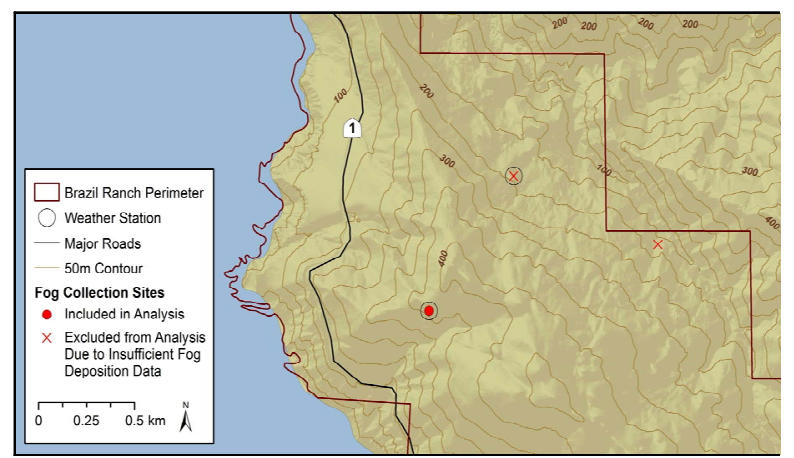

Figure 2. Fog collector locations.

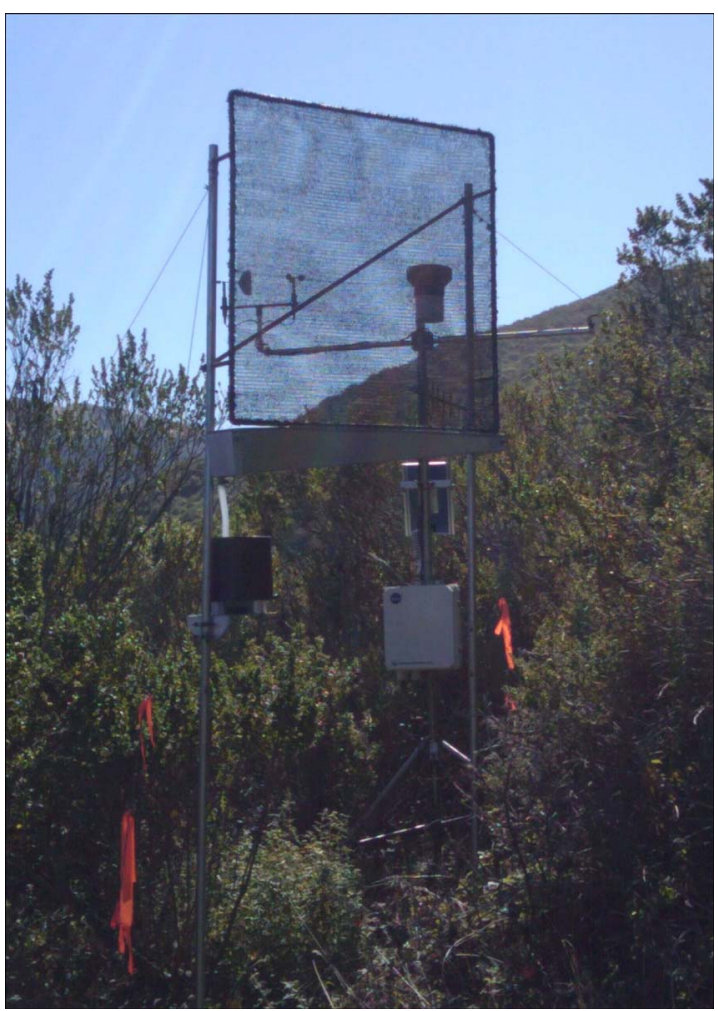

Figure 3. Standard fog collector. 
tipping bucket rain gauge. The tipping bucket rain gauge on the fog collector recorded the amount of water collected over 15.0 minute intervals. Measurements based on water collected from the mesh screens were removed from the fog record when they occurred within an hour of precipitation events recorded on the adjacent Campbell weather station, this helps to minimize the risk of erroneously interpreting water from rain as collected fog. Meteorological and fog deposition data were collected at the fog collection site during 128 days in 2010 and 74 days in 2011. Two of the installed fog collectors were not included in this study because insufficient fog deposition was recorded for deposition analysis. Figure 2 shows the location of the fog collectors and weather stations.

\section{Results}

The maximum wind speed during the 2010 fog collection period was $9.42 \mathrm{~m} / \mathrm{s}$ with an average daily maximum of $5.38 \mathrm{~m} / \mathrm{s}$ and an average wind speed of $3.13 \mathrm{~m} / \mathrm{s}$. During the 2011 fog collection period the maximum wind speed was $12.54 \mathrm{~m} / \mathrm{s}$ with an average daily maximum of 4.32 $\mathrm{m} / \mathrm{s}$ and an average wind speed of $2.44 \mathrm{~m} / \mathrm{s}$ (Figure 4). Wind rose plots in Figure 5 show the diurnal variation of wind direction and speed over three 8 -hour periods. The prevailing wind direction was generally from the northeast with winds from the northwest and southwest increasing in frequency and magnitude in the between the hours of 7:00 and 15:00. A histogram of wind direction for all hourly records also shows most winds approaching from the north-between $350^{\circ}$ and $40^{\circ}$ with winds directed from the south and north east with less frequency (Figure 6).

The dew-point depression ranged from $0.33^{\circ} \mathrm{C}$ to $38.80^{\circ} \mathrm{C}$ with an average of $4.44^{\circ} \mathrm{C}$. The distribution of dew-point depression values is skewed sharply to the right. Thirty-nine percent of hourly records had a dewpoint depression below $1{ }^{\circ} \mathrm{C}$ (Figure 7).

Fog deposition occurred during $73 \%$ of days recorded in 2010 and $87 \%$ of days recorded in 2011. Average hourly fog deposition in 2010 was higher than 2011 during the early half of the summer, but lower during the latter half. In 2010 the month with the highest average hourly fog deposition was June at $0.15 \mathrm{~L} / \mathrm{m}^{2}$, but in 2011 the peak occurred a month later at $0.24 \mathrm{~L} / \mathrm{m}^{2}$. Figure 8 shows a comparison of the trends in monthly fog deposition. However, only 3 days in June and 10 days in September are compared in this chart because the 2011 data was collected from June 28 through September 10.

In 2010, the total amount of fog deposition was 292.77 $\mathrm{L} / \mathrm{m}^{2}$ with a daily average of $2.29 \mathrm{~L} / \mathrm{m}^{2}$ and a daily maximum of $13.62 \mathrm{~L} / \mathrm{m}^{2} .2010$ had an hourly average of $0.1 \mathrm{~L} / \mathrm{m}^{2}$ and an hourly maximum of $2.31 \mathrm{~L} / \mathrm{m}^{2}$. In 2011 the total fog deposition was $285.66 \mathrm{~L} / \mathrm{m}^{2}$, the daily average was $3.86 \mathrm{~L} / \mathrm{m}^{2}$, and the daily maximum was 17.75

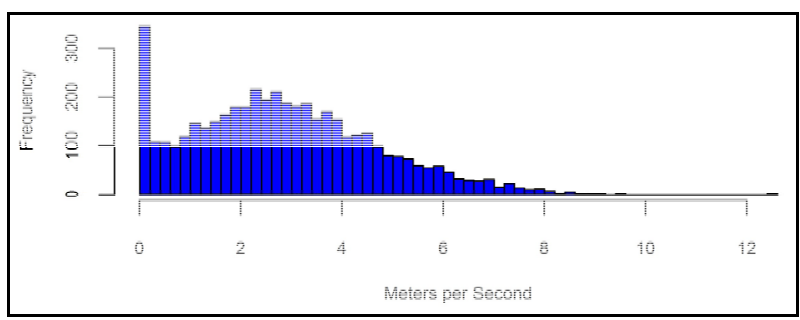

Figure 4. Wind speed during the 2010 and 2011 fog collection periods.

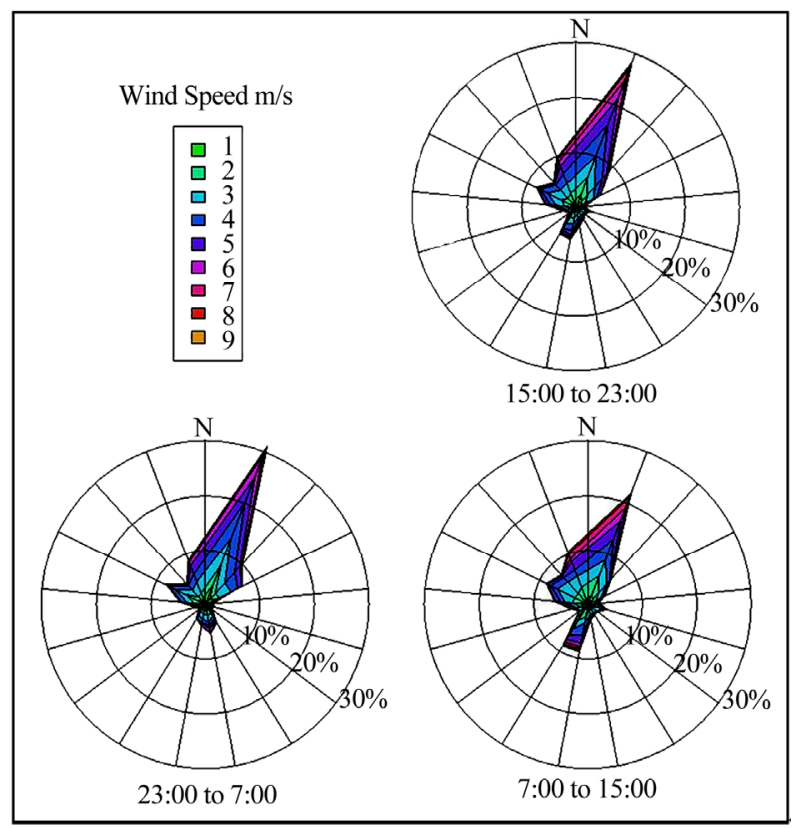

Figure 5. Diurnal wind direction during the 2010 and 2011 fog collection periods.

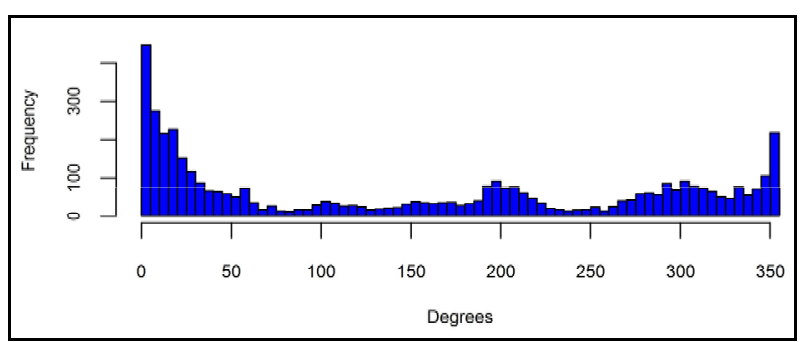

Figure 6. Wind direction during the 2010 and 2011 fog collection periods.

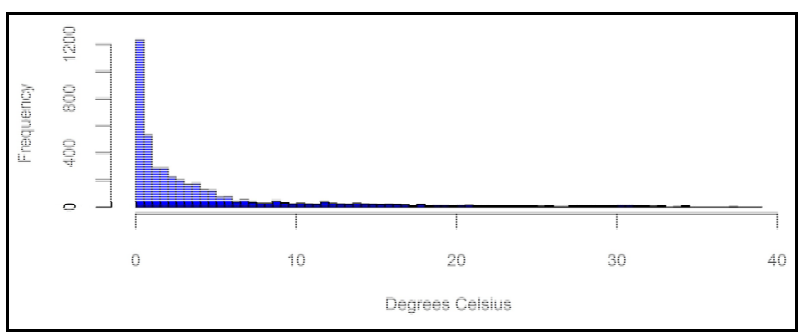

Figure 7. Dew-point depression during the 2010 and 2011 fog collection periods. 
$\mathrm{L} / \mathrm{m}^{2}$. In 2011 the hourly average was $0.17 \mathrm{~L} / \mathrm{m}^{2}$ with an hourly maximum of $2.42 \mathrm{~L} / \mathrm{m}^{2}$. Figures 9 and $\mathbf{1 0}$ show the hourly values over the 2010 and 2011 fog collection seasons, respectively.

Most fog deposition occurred during the night and early morning hours. Average fog deposition was approximately $0.16 \mathrm{~L} / \mathrm{m}^{2}$ between the hours of 20:00 and 2:00 increasing to a peak of about $0.21 \mathrm{~L} / \mathrm{m}^{2}$ between 3:00 and 9:00. After 9:00 average fog deposition steeply declined to nearly 0.0 between the hours of 14:00 and 18:00. The median dew-point depression followed an opposite diurnal trend indicating fog deposition occurred when the dew-point depression was low (Figure 11).

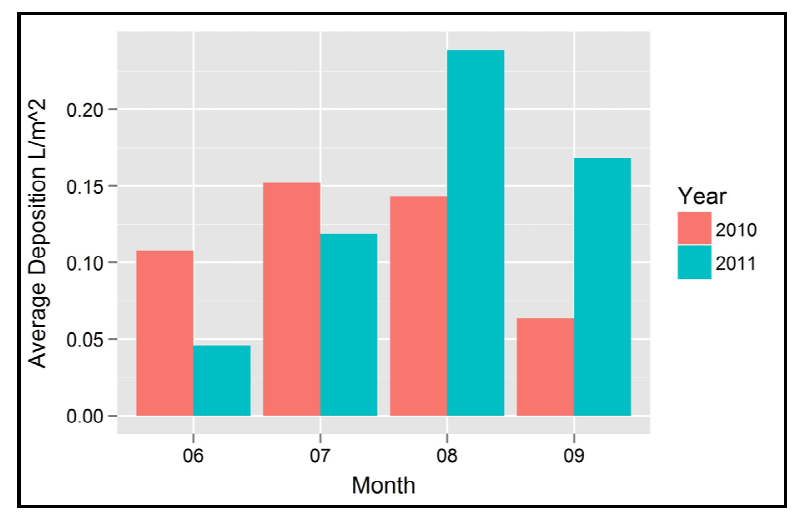

Figure 8. Average hourly fog deposition by month.

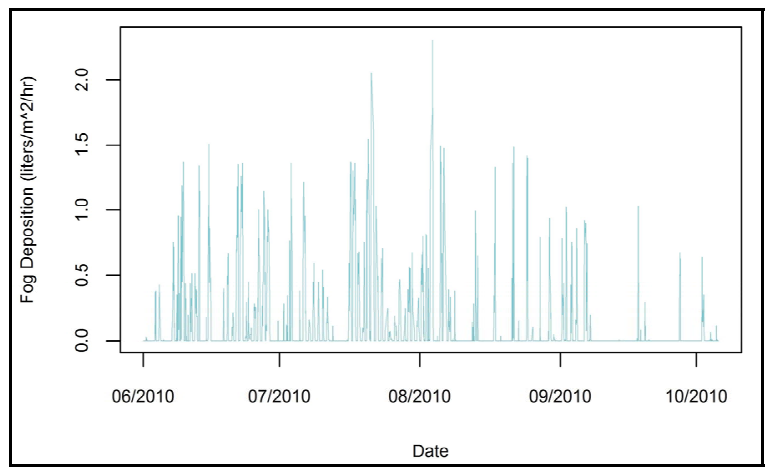

Figure 9. Hourly fog deposition 2010.

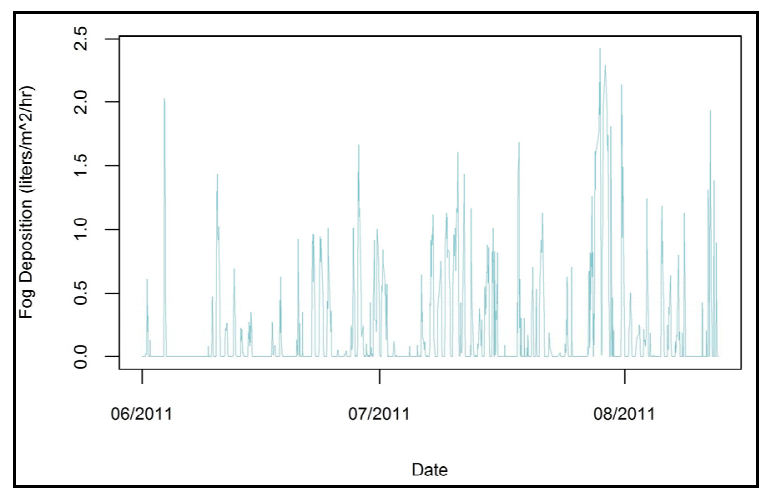

Figure 10. Hourly fog deposition 2011.
The dew-point depression was a strong indicator for the presence and absence of fog deposition. Table 1 shows a confusion matrix for the prediction of fog deposition when the hourly dew-point depression was at or below $0.5^{\circ} \mathrm{C}$. Using this threshold, the rate of correctly predicting fog deposition when fog deposition occurred (true positive rate) was $76.9 \%$. The rate of predicting no fog deposition when no fog deposition occurred (true negative rate) was $94 \%$. The precision of predicting fog deposition, which represents the ratio of correct positive predictions to the total number of positive predictions, was $88.1 \%$. Adjusting for the imbalance between the number of fog events and no fog events, we used the geometric mean as an additional measure of performance [18]. This value was $82.3 \%$.

High wind speeds typically accompanied increased rates of fog deposition during periods of low dew-point depression. A time series plot of the 2010 fog collection period shows a roughly similar trend between changes in fog deposition and wind speed (Figure 12).

A linear relationship between wind speed and the quantity of fog deposition was observed in hourly records with a dew-point depression below $0.38^{\circ} \mathrm{C}$ (Figure 13). This relationship was slightly stronger during periods that not only had a dew-point depression under $38^{\circ} \mathrm{C}$, but were also subjected to prevailing winds (between $350^{\circ}$ and $40^{\circ}$ ) (Figure 14). The number of fog records that met these meteorological criteria was, however, limited. Only 209 records had a dew-point depression under $0.38^{\circ} \mathrm{C}$ and of these only 123 occurred during prevailing winds.

Table 1. Fog deposition confusion matrix based on an hourly dew-point depression at or below $0.5^{\circ} \mathrm{C}$.

\begin{tabular}{cccc}
\hline & $\begin{array}{c}\text { No Fog } \\
\text { Predicted }\end{array}$ & Fog Predicted & $\begin{array}{c}\text { True Prediction } \\
\text { Rate }\end{array}$ \\
\hline No Fog & 2985 & 144 & $95.4 \%$ \\
Fog & 319 & 1062 & $76.9 \%$ \\
Precision & & $88.1 \%$ & \\
\hline
\end{tabular}

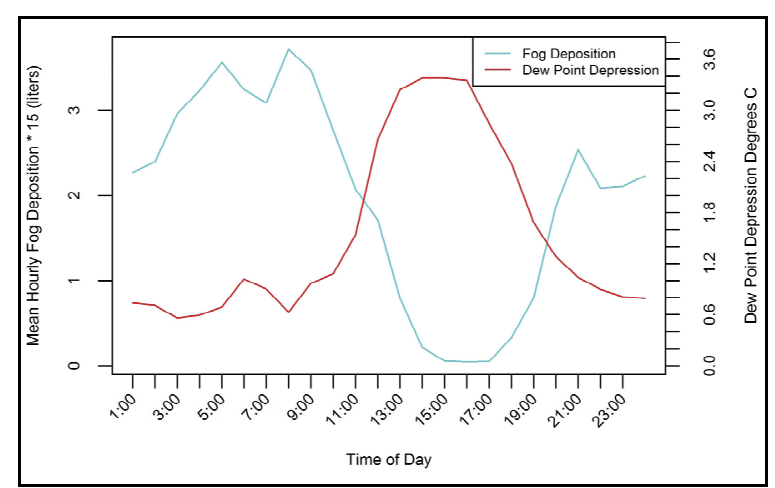

Figure 11. Diurnal fog deposition and dew-point depression. 


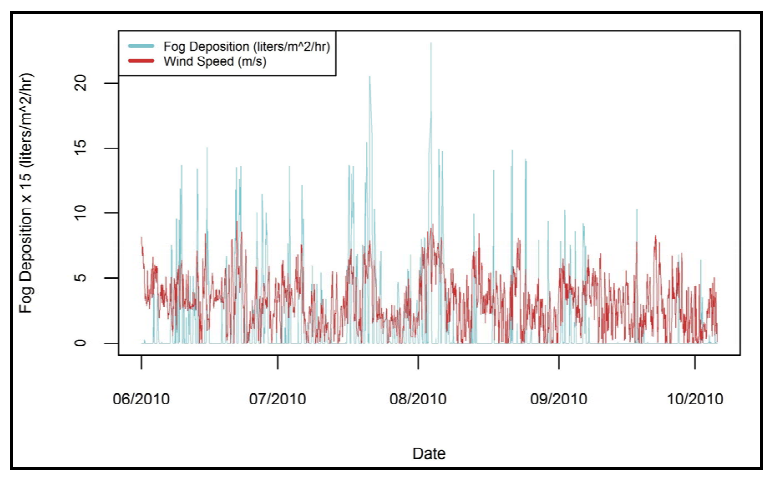

Figure 12. Fog deposition and wind speed time series.

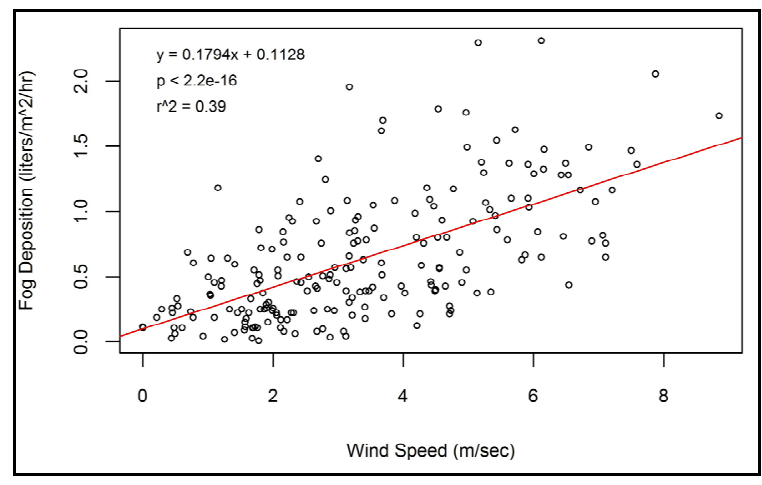

Figure 13. Fog deposition vs. wind speed.

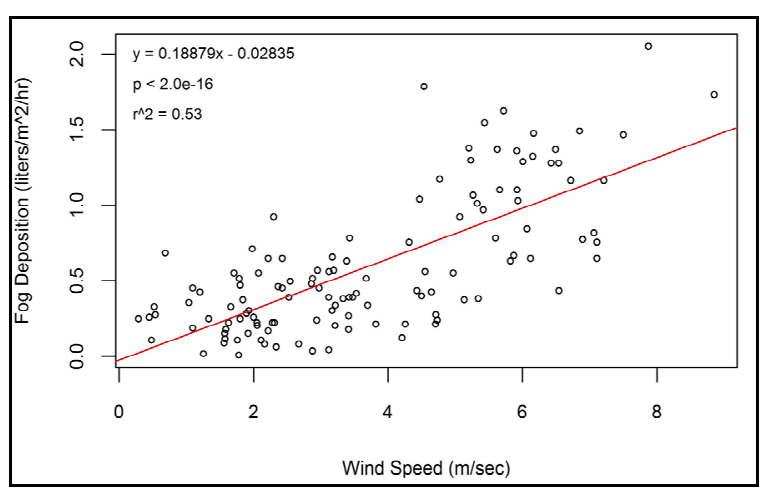

Figure 14. Fog deposition vs. wind speed during prevailing winds.

\section{Discussion}

Due to the absence of other fog collection studies on the California Central Coast, there is no local benchmark to compare the relative quantity of fog water collected at the Big Sur site. However, according to Schemenauer [19], a standard fog collector generally collects between 1 and $10 \mathrm{~L} / \mathrm{m}^{2} /$ day. Although the daily average $3.01 \mathrm{~L} / \mathrm{m}^{2}$ during peak fog months places the Big Sur fog collector at the lower end of that range, the Big Sur quantities are likely conservative due to the fact that some fog deposition was presumably excluded by omitting records contaminated by rainfall.
Fog deposition at the Big Sur site was typically found to occur when the dew-point depression drops below $0.5^{\circ} \mathrm{C}$. Dew-point depression has long been used as an indicator of fog formation; however, its reliability can vary by region and synoptic weather conditions [20]. Although our study only examined meteorological variables that influence fog deposition, other studies have drawn similar conclusions regarding the formation of fog. Grace and Ferriere [14], for example, demonstrated at a site in southeast Australia that a dew point depression below $1.0^{\circ} \mathrm{C}$, predicted the occurrence of fog with a probability between $60 \%$ and $90 \%$.

During periods of slightly lower dew-point depression, the quantity of fog deposition can be accurately predicted due to a positive, linear relationship between wind speed and the amount of fog intercepted by the collector. Wind speeds below $2.0 \mathrm{~m} / \mathrm{s}$ show very little correlation with fog deposition, but the relationship is evident at higher wind speeds. Estimates of fog deposition are more reliable when winds are moving in the prevailing direction. This may be due to physical characteristics of the prevailing winds, or simply due to the fact that the collector screen was oriented perpendicular to the prevailing wind direction allowing the screen to intercept fog droplets more effectively.

Despite the positive relationship between deposition and wind speed observed at the Big Sur site, the diurnal timing of wind speed does not favor fog deposition. Wind speeds were highest during the late morning - the same period in which the dew-point depression tends to increase and fog deposition decrease. Conversely, wind speeds generally drop in the late evening and remain low through the morning. Figure 15 shows difference in the wind speed and fog deposition trends. This decrease in wind speed coincides with a drop in the dew-point depression and higher rates of fog deposition. Lundquist and Bourcy made similar observations in analyzing data from 13 meteorological stations along the California Coast. They found that observed fog was typically present when both air temperature and wind speeds were low [21].

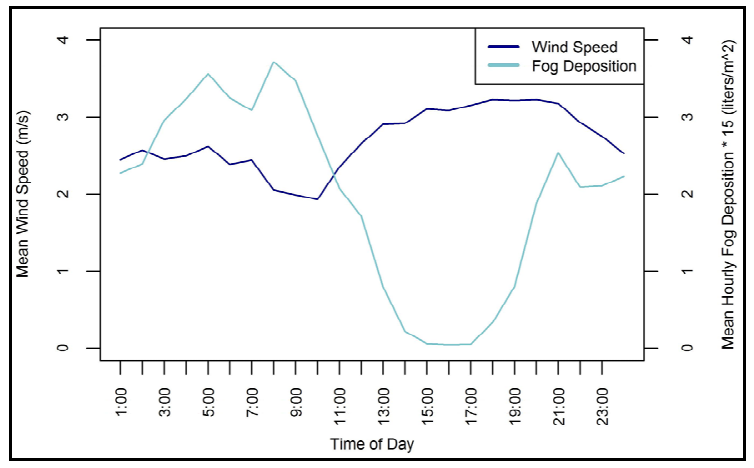

Figure 15. Diurnal trends in wind speed and fog deposition. 
Wind speed and direction are frequently cited as drivers of fog water deposition in fog collection studies [22,23]. This is due simply to the fact that faster and more direct winds transport more fog droplets horizontally into the collector mesh. How much fog deposition occurs vertically in the absence of wind is unaddressed by this study. However, Frumau et al. note that, in many cases, only small amounts of fog fall vertically to the ground relative to horizontally deposited fog or rainfall.

Another reason why wind speed is an important component of fog deposition is the efficiency of the SFC increases with increasing wind speed. Schemenaur [23] found that for a screen with a mesh density of $70 \%$, fog collection efficiency was only $30 \%$ at $0.5 \mathrm{~m} / \mathrm{s}$, but at 8.0 $\mathrm{m} / \mathrm{s}$, collection efficiency increased to just over $60 \%$. Gains in efficiency, however, decreased with increasing wind speed. Fog collector efficiency is also dependent on droplet size. Schemenaur also found that efficiency in collecting large droplets $(15 \mu)$ increased faster with increases in wind speed than did the efficiency of collecting smaller droplets $(11 \mu)$. Changes in efficiency at different wind speeds and the dependence of fog collector efficiency on droplet size may explain some of the residuals observed in our regression model results.

A better understanding of the timing between fog collection and changes in wind speed may also improve our ability to predict deposition. Because the fog collectors are in a remote location, we were unable to directly observe the timing between increases in wind speed and the collection of fog deposition by the logger. In matching our fog deposition records to anemometer readings we observed many instances of elevated wind speed prior to increases in fog deposition. We suspect that acceleration of wind speed would more closely match increases in fog deposition were it not for these apparent lags.

We surmise high rates of summer fog deposition, by increasing soil water content, may help sustain the productivity of Big Sur vegetation through periods of low rainfall. Joslin et al. [24,25] demonstrated that trees collect fog deposition at approximately the same rate as a passive string fog collector. These results suggest Cali-

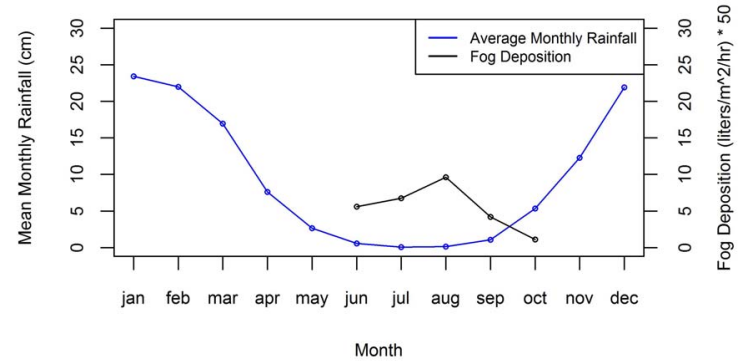

Figure 16. Average monthly precipitation for years 19812010 in Big Sur, CA and average hourly fog deposition for the 2010 and 2011 fog collection periods. fornia Coastal shrubs may also function as highly efficient fog collectors, intercepting fog deposition and channeling the water to their root systems via fog-drip. On the Point Reyes peninsula, a California coastal area approximately $200 \mathrm{~km}$ north of Big Sur, Ingraham and Matthews [6] compared water isotopes of soil water before and after the summer fog season. They not only found the isotope matching fog drip permeated to the root zone of conifer trees, but also that fog drip was present in the tree cores of conifers. If fog drip is a source of soil water in Big Sur as it is in Point Reyes, the timing would likely be advantageous for Big Sur vegetation. During both the 2010 and 2011 summers, fog deposition at the Big Sur site was highest in July and August. This increase in fog deposition coincides with a period of very low rainfall characteristic of California's Mediterranean climate. Figure 16 shows a 30-year average of monthly rainfall at a NOAA [24] weather station approximately $15.8 \mathrm{~km}$ southeast of our study site. This figure also shows that as rainfall decreases in the summer months, fog deposition increases, and as the region receives more rainfall in early autumn, fog deposition declines.

The amount of fog deposition may compose a large portion of the overall water budget for the region. To estimate the amount of fog deposition that the oceanfacing slopes of Brazil Ranch may potentially receive, we calculated the average slope of the ocean-facing coastline within Brazil Ranch. At an average slope of 27.01 degrees, a $1 \mathrm{~m} \times 1 \mathrm{~m}$ fog collector would represent $2.2 \mathrm{~m} \times 1 \mathrm{~m}$ of hillside surface. The daily average of fog deposition for both seasons was $3.01 \mathrm{~L}$. Assuming that the $2.2 \mathrm{~m}^{2}$ receives the same amount of deposition as a $1 \mathrm{~m} \times$ $1 \mathrm{~m}$ SFC, the daily average fog deposition on the hillside surface is approximately $1.3 \mathrm{~cm} /$ day.

This value well exceeds the average rainfall for the same period which was only $0.2 \mathrm{~cm} /$ day.

This study is an initial step towards a better understanding of the quantities of fog deposition that occur on the California Coast, the local weather conditions that drive fog deposition, and how fog deposition may affect coastal vegetation productivity. Future analysis will include data from more fog collector locations to better characterize fog deposition in the region, as well as comparisons between fog collector efficiency and the collection efficiency of California coastal scrub plant species.

\section{REFERENCES}

[1] J. Azevedo and D. L. Morgan, "Fog Precipitation in Coastal California Forests," Ecology, Vol. 55, No. 5, 1974, pp. 1135-1141. doi:10.2307/1940364

[2] H. A. Ewing, K. C. Weathers, P. H. Templer, T. E. Dawson, M. K. Firestone, A. M. Elliott and V. K. S. Boukili, "Fog Water and Ecosystem Function: Heterogeneity in a 
California Redwood Forest," Ecosystems, Vol. 12, No. 3, 2009, pp. 417-433. doi:10.1007/s10021-009-9232-x

[3] D. T. Fischer, C. J. Still and A. P. Williams, "Significance of Summer Fog and Overcast for Drought Stress and Ecological Functioning of Coastal California Endemic Plant Species," Journal of Biogeography, Vol. 36, No. 4, 2009, pp. 783-799. doi:10.1111/j.1365-2699.2008.02025.x

[4] T. E. Dawson, "Fog in the California Redwood Forest: Ecosystem Inputs and Use by Plants," Oecologia, Vol. 117, No. 4, 1998, pp. 476-485. doi: $10.1007 / \mathrm{s} 004420050683$

[5] S. S. O. Burgess and T. E. Dawson, "The Contribution of Fog to the Water Relations of Sequoia Sempervirens (D. Don): Foliar Uptake and Prevention of Dehydration," Plant Cell Environment, Vol. 27, No. 8, 2004, pp. 1023-1034. doi:10.1111/j.1365-3040.2004.01207.x

[6] N. L. Ingraham and R. A. Matthews, "The Importance of Fog-Drip Water to Vegetation-Point Reyes Peninsula, California," Journal of Hydrology, Vol. 164, No. 1-4, 1995, pp. 269-285. doi:10.1016/0022-1694(94)02538-M

[7] J. D. Corbin, M. A. Thomsen, T. E. Dawson and C. M. D'Antonio, "Summer Water Used by California Coastal Prairie Grasses: Fog, Drought, and Community Composition," Oecologia, Vol. 145, No. 4, 2005, pp. 511-521. doi:10.1007/s00442-005-0152-y

[8] S. Petterssen, "On the Causes and the Forecasting of the California Fog," Journal of the Aeronautical Sciences, Vol. 3, No. 9, 1936, pp. 305-309.

[9] R. J. Pilie', E. J. Mack, C. W. Rogers, U. Katz and W. C. Kocmond, "The Formation of Marine Fog and the Development of Fog Stratus Systems along the California Coast," Journal of Applied Meteorology, Vol. 18, No. 10, 1979, pp. 1275-1286. doi:10.1175/1520-0450(1979)018<1275:TFOMFA $>2.0 . C$ $\underline{\mathrm{O} ; 2}$

[10] D. Koračin, J. Lewis, W. T. Thompson, C. E. Dorman and J. A. Businger, "Transition of Stratus into Fog along the California Coast: Observations and Modeling," Journal of Atmospheric Sciences, Vol. 58, No. 13, 2001, pp. 1714-1731.

doi:10.1175/1520-0469(2001)058<1714:TOSIFA $>2.0 . \mathrm{C}$ $\mathrm{O} ; 2$

[11] D. Stow, Y. Hamada, L. Coulter and Z. Anguelova, "Monitoring Shrubland Habitat Changes through Object-Based Change Identification with Airborne Multispectral Imagery," Remote Sensing of Environment, Vol. 112, No. 3, 2008, pp. 1051-1061. doi:10.1016/j.rse.2007.07.011

[12] D. F. Leipper, "Fog Forecasting Objectively in the California Coastal Area Using LIBS," Weather and Forecasting, Vol. 10, No. 4, 1995, pp. 741-762. doi:10.1175/1520-0434(1995)010\%3C0689:DCOSTS $\% 3$ E2.0.CO;2

[13] L. De La Fuente, Y. Delage, S. Desjardins, A. Macafee, G.
Pearson and H. Ritchie, "Can Sea Fog be Inferred from Operational GEM Forecast Fields?" Earth and Environmental Science, Vol. 164, 2007, pp. 1303-1325. doi:10.1007/s00024-007-0220-9

[14] W. Grace and P. Ferriere, "Statistical-Empirical Forecasting Guidance for the Occurrence of Fog at Mount Gambier Airport," Australian Meteorological Magazine, Vol. 50, 2001, pp. 15-27. http://www.bom.gov.au/amm/docs/2001/grace.pdf

[15] L. Caceres, B. Gomez-Silva, X. Garro, V. Rodriguez, V. Monardes and C. P. McKay, "Relative Humidity Patterns and Fog Water Precipitation in the Atacama Desert and Biological Implications," Journal of Geophysical Research, Vol. 112, No. G4, 2007, 11 pp. doi:10.1029/2006JG000344

[16] P. Henson and D. J. Usner, "The Natural History of Big Sur," University of California Press, Berkeley and Los Angeles, 1993.

[17] R. S. Schemenauer and P. Cereceda, "A Proposed Standard Fog Collector for Use in High-elevation Regions," Journal of Applied Meteorology, Vol. 33, No. 11, 1994, pp. 1313-1322.

doi:10.1175/1520-0450(1994)033\%3C1313:APSFCF\%3 E2.0.CO;2

[18] M. Kubat, R. Holte and S. Matwin, "Machine Learning for the Detection of Oil Spills in Satellite Radar Images," Machine Learning, Vol. 30, No. 2-3, 1998, pp. 195-215. doi:10.1023/A:1007452223027

[19] R. S. Schemenauer and P. Cereceda, "Fog-Water Collection in Arid Coastal Locations," Ambio, Vol. 20, No. 7, 1991, pp. 303-308.

[20] R. E. Newell, "Comments on 'The Forecasting of Winter Fog: A Geographical Approach'," Journal of Applied Meteorology, Vol. 3, No. 3, 1964, pp. 342-343. doi: 10.1175/1520-0450(1964)003\%3C0342:COFOWF\% 3E2.0.CO;2

[21] J. D. Lundquist and T. B. Bourcy, "California and Oregon humidity and coastal fog," 14th Conference on Boundary Layers and Turbulence, Colorado, 2000.

[22] J. Oliver, "Fog Water Harvesting along the West Coast of South Africa: A Feasibility Study," Water SA, Vol. 28, No. 34, 2002, pp. 349-360.

[23] R. S. Schemenaur and P. I. Joe, "The Collection Efficiency of a Massive Fog Collector," Atmospheric Research, Vol. 24, No. 1-4, 1989, pp. 53-69. doi:10.1016/0169-8095(89)90036-7

[24] NOAA, “1981-2010 Climate Normals, Big Sur Station,” http://gis.ncdc.noaa.gov/map/cdo/

[25] J. D. Joslin, S. F. Mueller and M. H. Wolfe, "Tests of Models of Cloudwater Deposition to Forest Canopies Using Artificial and Living Collectors," Atmospheric Environment, Vol. 24A, No. 12, 1990, pp. 3007-3019. http://www.sciencedirect.com/science/article/pii/0960168 69090480B 